\title{
Improvement of Longwall Face Environment Using New Ventilation Systems
}

by Hiromichi YAMASHITA, Ken-ichi UCHINO, Tsutomu IKEDA, Shunsuke HATA and Hajime TATSUMOTO

Investigations for improving the environmental conditions of the longwall faces in Yotsuyama Mine, Miike Colliery, were conducted using new ventilation systems. The E-shaped ventilation system is the one and the W-Shaped ventilation system is the other.

The results obtained are

(1) Both systems are effective for controlling the environmental conditions of the face worked in highly heated surrounding rocks.

(2) Ventilating by $\mathrm{Wr}$-System, labour intesive areas are placed in fresh air and the total capacity of heat exchangers required for a face including face entries are only 60 to $70 \%$ of that required in the Ur-System.

(3) In the Wr-System, two patterns of ventilation air flow is observed due to the different flow rates in the two intake airways.

(4) In gassy areas, the $\mathrm{Wr}$-System could be inadequate because of the tendency of fire-damp accumulation in the goaf. In such cases, the E-System should be applied.

\section{〔2-7〕三井砂川炭鉱の深部採掘について}

\section{1. 緒}

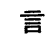

砂川炭鉱は大正 3 年開坑以来, 69 年の歴史を持ち, その間幾多 の技術的変遷を経て, 今日に至つている。急傾斜炭鉱特有の難か しい諸条件と, 早いテンポの深部移行度に伴う保安, 生産上の諸 問題克服のため, 過去関連技術を含めたところの採掘技術の改善 に取り組んできた。その中でも特筆すべきことは, 昭和39年より 水力採炭法を採用したことである。その後水力採炭技術の改善を 着実に図りつつ, その適用範囲を逐次拡大することで, 深部化に 伴う諸問題の解決と生産コストの上昇を押えてきた。

現在当炭鉣の主力である水力採炭は地表下約 $900 \sim 1,000 \mathrm{~m}$ の深 部区域で安定して操業されている。本稿では $900 \mathrm{~m}$ 以深採掘に備 えてとつた事前施策および事後施策の中で特に成果が認められる ものにつきその概況を報告するものである。

\section{2. 採 掘 概 要}

当炭鉱は石狩炭田北端の北空知地区に位置し東西約 $8 \mathrm{~km}$, 南北 約 $12 \mathrm{~km}$ で鉱区面積は $73 \mathrm{~km}^{2}$ である。稼行炭層は開坑以来美唄， 登川両夾炭層を対象としてきたが, 昭和 52 年以降は美唄夾炭層の みに集約, 稼行している。現在の採掘区域は鉱区北端の砂川断層 と南端の空知断層間に賦存する走向約 $7 \mathrm{~km}$ 間である。 炭層傾斜は西 $50 \sim 70^{\circ}$ の傾斜を持ち走向はほぼ南北である。 操業坑口は第一坑坑口に集約しており, 採掘部内を南部部内と 北部部内に 2 分している。主力の南部部内は全区域水力採炭法で, 北部部内は全区域欠口全充てん採炭法で出炭している。採掘レべ ルは北部部内が海抜 $-460 \sim 560 \mathrm{~m}$ （地表下 $600 \sim 700 \mathrm{~m}$ ）に対 し, 南部部内は海抜 $-760 \sim 860 \mathrm{~m}$ （地表下 $900 \sim 1,000 \mathrm{~m}$ )である。 したがつて本稿では水力採炭を実施している南部部内に重点をお き報告する(第 $1 \sim 2$ 図, 第 1 表参照)。

\section{3. 諸施策とその効果}

\section{$3 \cdot 1$ 水力採炭規模の拡充}

急傾斜炭鉱における水力採炭の有利性についてはよく言及され

1. 三井石炭鉱業株式会社砂川鉱業所鉱務課長

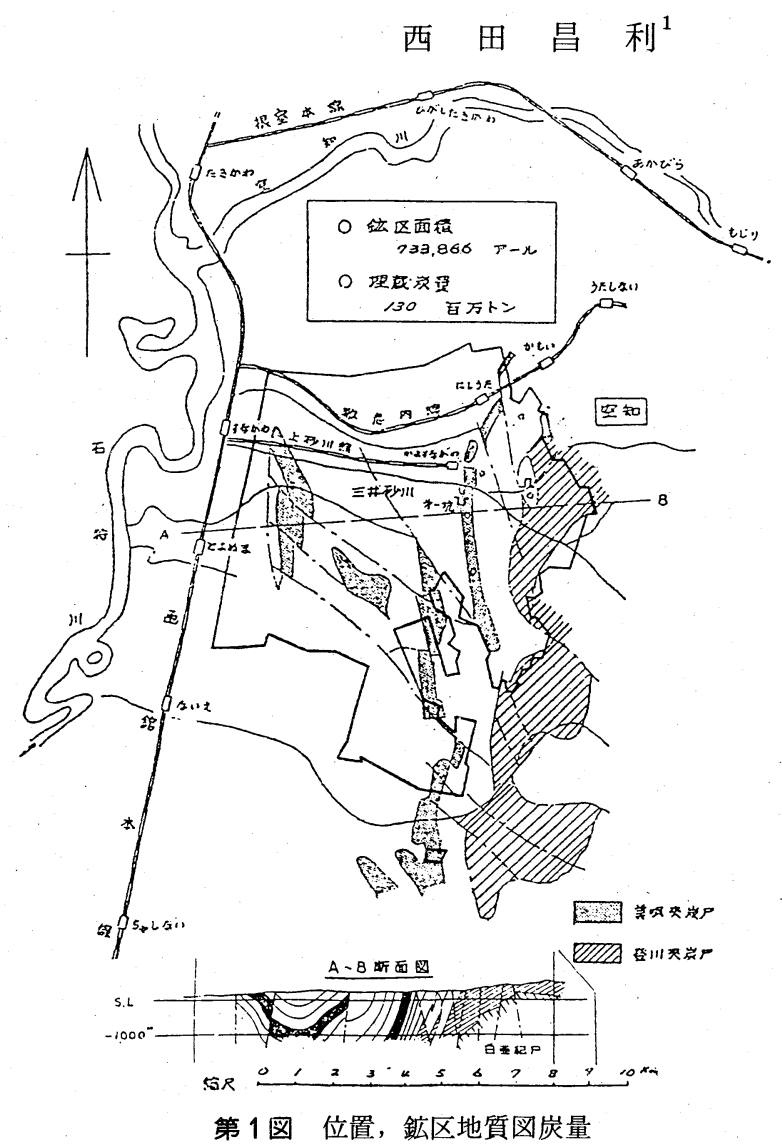

第 1 表 第一坑南部部内, 北部部内比較表

\begin{tabular}{|c|c|c|c|c|c|}
\hline 部内項目 & 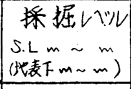 & 採炭方式 & 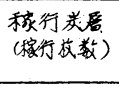 & $\begin{array}{l}57 \text { 年度 } \\
\text { 出类此平 } \\
(\%)\end{array}$ & $\begin{array}{l}\text { 57年度 } \\
\text { 部内数 }\end{array}$ \\
\hline 南部部内 & $\begin{array}{l}-760 \sim-860 \\
(900 \sim 1,000\end{array}$ & 水力採炎法 & 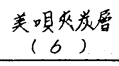 & 78 & 3 \\
\hline 北部 部内 & $\begin{array}{l}-460 \sim-560 \\
(600 \sim 700)\end{array}$ & 久口棌岸法 & $\begin{array}{c}\text { 美唄夷应居 } \\
(5)\end{array}$ & $\alpha 2$ & I \\
\hline
\end{tabular}

ているが，当炭鉱では永年にわたり培かつた諸実績に，その時々 の自然条件, 人的, 設備能力等につき十分検討を加え, 逐次水力 


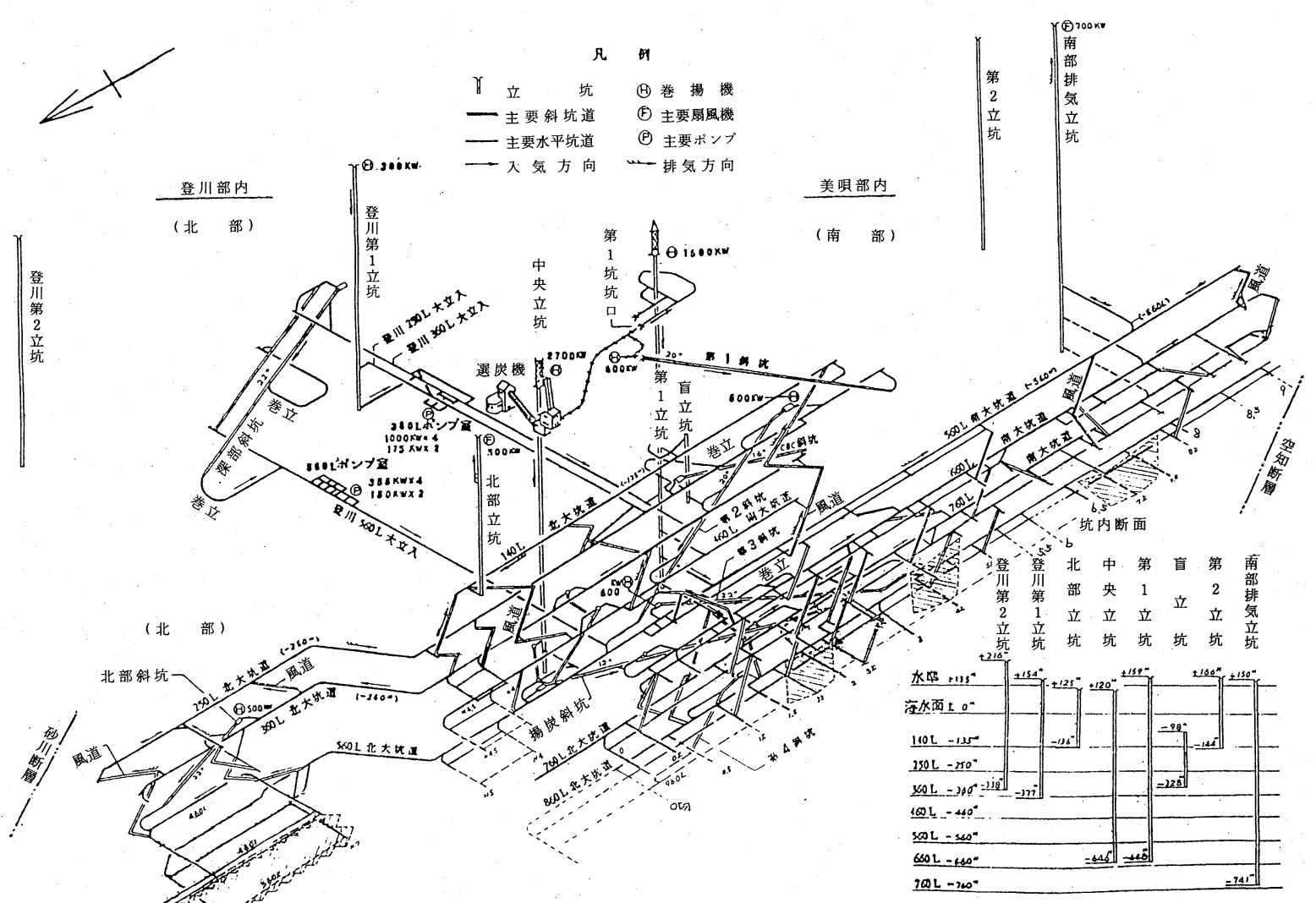

第2図坑内骨格図

第 2 表 出炭, 人員, 能率

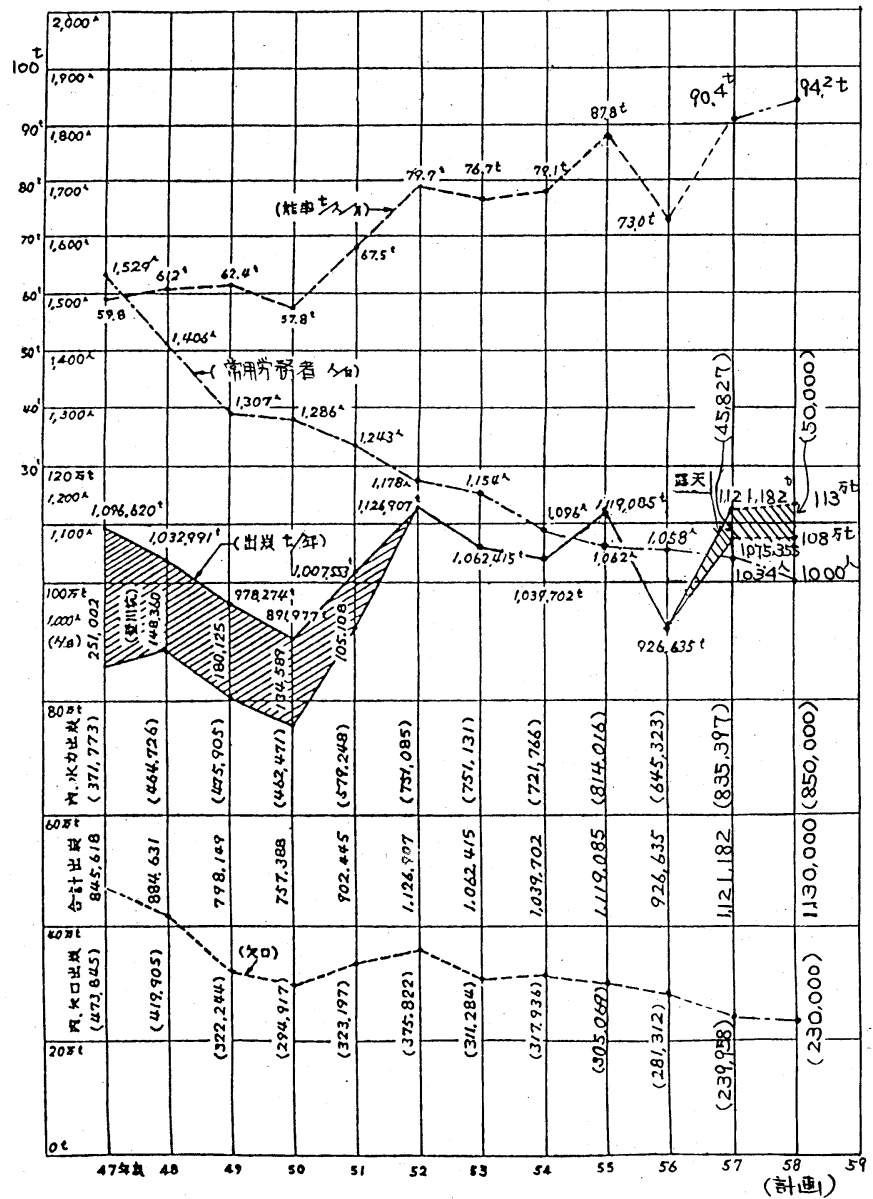

採炭規模を拡大することを基本施策としてきた。これにより 深部化により増加するマイナス要因を吸収し，生産性の維持 向上, 保安成績の向上に結びつけた (第 $2,3,4,5$ 表参照)。

\section{$3 \cdot 2$ 坑内骨格の整備合理化}

深部採掘の進展に伴い予想される盤圧, ガス, 自然発火, 温度, 運搬等の技術的諸問題解決の基本的対策として次の施 策をとつた。

（1）南部排気立坑の新規開さくと主扇の切替え $760 \mathrm{~L}$ 以深採掘体制確立のため, 昭和 52 年 3 月より南部排気立坑 （本体内径 $5.5 \mathrm{~m}$, 長さ $891 \mathrm{~m}$ ) の開さくに着手, 昭和 54 年 6 月に完成した。引続き同年 10 月主扇切替工事 ( 第 2 立坑旧 $500 \mathrm{~kW}$ 主扇停止と南部排気立坑新規 $700 \mathrm{~kW}$ 主扇切替運転

第3表 年度別負傷統計表

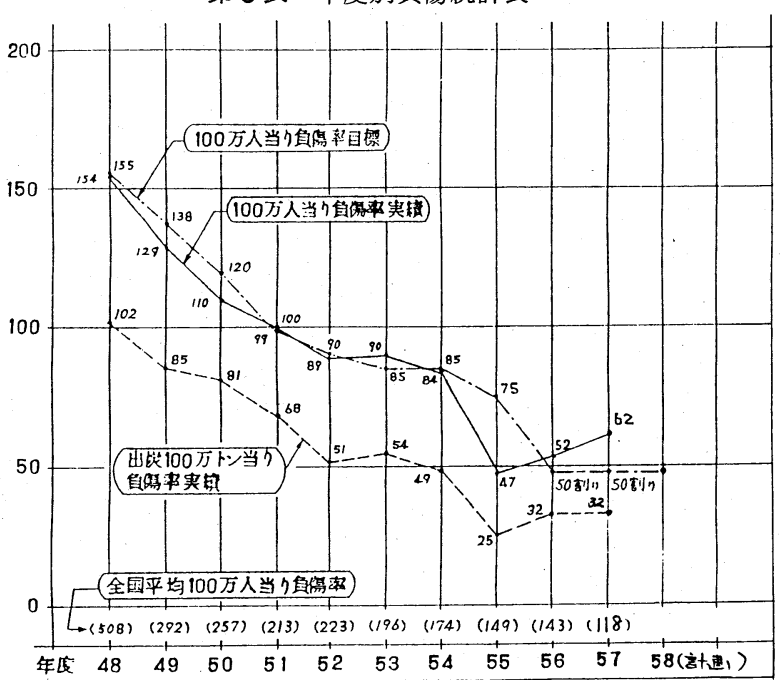


第 4 表 水力採炭, 産炭比率推移と生産性の関係, 災害率推移

\begin{tabular}{|c|c|c|c|c|c|c|c|c|c|c|c|c|}
\hline 年度 & $\begin{array}{c}47 \\
\text { (美䅐) }\end{array}$ & 48 & $\left.\begin{array}{c}49 \\
(1)\end{array}\right)$ & $\begin{array}{l}50 \\
(=)\end{array}$ & $\begin{array}{l}51 \\
(\because)\end{array}$ & $\begin{array}{r}52 \\
62,\end{array}$ & $\begin{array}{r}53 \\
(\%)\end{array}$ & $\begin{array}{l}54 \\
(1,)\end{array}$ & $\begin{array}{l}55 \\
(1,1)\end{array}$ & $\begin{array}{c}56 \\
(5,)\end{array}$ & 57 & $\begin{array}{c}58 \\
(5+1)\end{array}$ \\
\hline 久口採求 & $43^{2 .}{ }^{\%}$ & $40 . b$ & $32^{9}$ & 33.1 & $32 . !$ & $33^{3}$ & $29^{3}$ & 30.6 & $27 .^{3}$ & 30.4 & $22^{3}$ & $21^{3}$ \\
\hline 水力㥒搏 & $5 b^{8} \%$ & 594 & 67.1 & 66.9 & $67^{9}$ & $b b^{7}$ & 70.7 & $69^{4}$ & 72.7 & 69.4 & T7. 7 & 787 \\
\hline & $100^{\%}$ & 100 & 100 & 100 & 100 & 100 & 100 & 100 & 100 & 100 & 100 & 100 \\
\hline 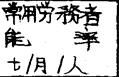 & $59^{8}$ & $\left.b\right|^{2}$ & $b 2^{4}$ & $57^{8}$ & $67^{5}$ & 79.7 & $76 .^{7}$ & 79.1 & 87.8 & $73^{\circ}$ & $\begin{array}{r}86.7 \\
(90.4) \\
\end{array}$ & $\begin{array}{r}90^{\circ} \\
\left(94^{2}\right) \\
\end{array}$ \\
\hline 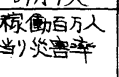 & 172 & 154 & 129 & 110 & 100 & 89 & 90 & 84 & 47 & 52 & b2 & 50剖り \\
\hline 偖考 & & 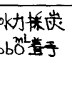 & & & 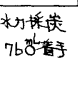 & & & & & 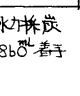 & & \\
\hline
\end{tabular}

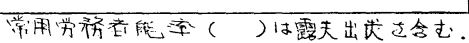

する。また盤下卸周辺部付近の残炭柱をモ ニター操作法の改善により完全採掘するこ とを可能とし, 周辺坑道の維持管理に効果 を上げた。なお場外長期維持坑道はできる だけじよう乱影響後に掘さくするようにし ている。

(b) 坑道位置の選定 先行採掘となる サブレベル坑道間隔を $760 \mathrm{~L}$ までの $18 \mathrm{~m}$ 規 格より $24 \mathrm{~m}$ に拡大した。坑道維持上はもと より坑道掘進メートルの節減, および採炭 メートル当り出炭増等の生産性の向上にも つながつた。

(c) 坑道支保の選定

（i）先行サブレベル坑道三ツ枠に一部鯖
第 5 表 採炭切羽総括 (昭和 58 年 2 月実績)

\begin{tabular}{|c|c|c|}
\hline & $\begin{array}{l}\text { 第一坑 } \\
\text { (北神久) }\end{array}$ & 算一坑 \\
\hline 長正地场羽数 & $30^{\circ}$ & \\
\hline 楼而面 $(\mathrm{m})$ & 1522 & \\
\hline 1日当出苃 $(3 / 8)$ & 903 & \\
\hline 平场场数 & & 4.4 台仿 \\
\hline 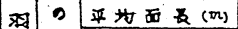 & & 21.7 \\
\hline 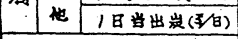 & & 2,716 \\
\hline 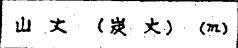 & $\begin{array}{l}2,05 \sim 1.47 \\
(1,30 \sim 13)\end{array}$ & $\begin{array}{l}3.4 b-1.43 \\
(3.10 \sim 1.31)\end{array}$ \\
\hline 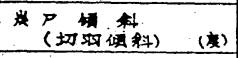 & $\begin{array}{c}59-54 \\
(32)\end{array}$ & $\begin{array}{l}74=59 \\
(74-59)\end{array}$ \\
\hline 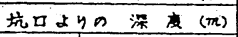 & -689 & $-977 \sim-951$ \\
\hline 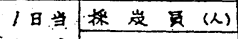 & 59 & 40 \\
\hline 配场全 & 76 & 53 \\
\hline 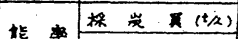 & 15.4 & $68^{8}{ }^{8}$ \\
\hline IE 扬羽全 $(t / 2)$ & 11.9 & 51,6 \\
\hline 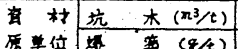 & 0.023 & - \\
\hline 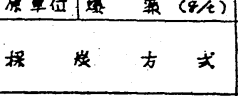 & 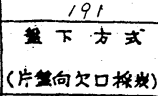 & 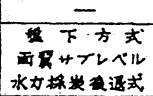 \\
\hline . & 全 克 塻 & 无 淖 \\
\hline 场 对 还 & 自些流下 & 流トラフ (标少) \\
\hline $\begin{array}{l}r \\
\text { 通 }\end{array}$ & B.C. $22.5 \mathrm{kvN} \times 4$ & $\begin{array}{l}\text { 月苟トラフ } \\
\text { 水カラン }\end{array}$ \\
\hline 极出距趡（m) & $3,900 \sim 3,780$ & $3,460-2,442$ \\
\hline 入 坑 距 部 & $4,960-4,790$ & $3,302-2,291$ \\
\hline 住得 时 (4) & $90-88$ & $72-49$ \\
\hline 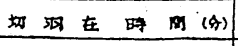 & $48 b-475$ & $541-5 i 5$ \\
\hline$(\%)$ & b4, 1 & $78 .^{9}$ \\
\hline
\end{tabular}

および不要坑道の放棄と包囲密閉工事 ) に着手, 同年 12 月完了した。これにより次の成果を得た。

(a) 維持坑道長を約 $16 \mathrm{~km}$ 減少できた。

(b) 坑道保守人員を 50 人/日 節減でき, 他部門へ振り向 けることができた。

(c) 旧密閉 119 䉪所を廃棄でき密閉管理の改善ができた。

(d) 有効風量率の上昇により部内風量が $2,000 \mathrm{~m}^{3} / \mathrm{min}$ 増 加した。その他所期の目的である当炭鉣 $760 \mathrm{~mL}$ 以深採掘 体制の基盤が確立した ( 第 6 表参照 )。

（2）登川主扇停止と一部坑道放棄 前記工事により登 川主扇停止と同部内の一部坑道 (約 $6 \mathrm{~km}$ ) の放棄が可能と なり, その分深部採掘のための諸施策へ力を振り向けるこ とができた (第 7 表参照)。

\section{$3 \cdot 3$ 水力採炭部内での保安, 生産上の諸施策}

(1) 盤正（坑道維持を主体とした）に対する施策

(a) 盤圧の制御 採掘の影響によるじよう乱作用をで きるだけ活用することを基本として，水力部内では地質・ 炭層条件によつては一部中間層を先行炭層として選択採掘
第 6 表 南部排気立坑主扇切替前と現状との通気実績対比

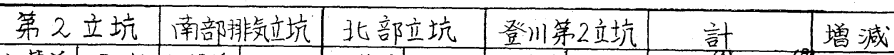

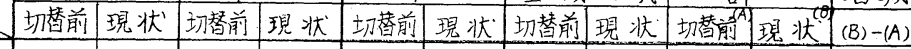

\begin{tabular}{|c|c|c|c|c|c|c|c|c|c|c|}
\hline 風 量 $\left(\mathrm{m}^{3} / \mathrm{min}^{2}\right)$ & 6,430 & C & 8,520 & 6.900 & 7.920 & 2,340 & ᄃ & 15,670 & 6.440 & +770 \\
\hline 勇压 (mMAq) & 208 & 休 & 165 & 170 & 217 & 250 & 休 & & & \\
\hline 等積孔 $\left(\mathrm{m}^{2}\right)$ & 2.88 & 止 & 4.20 & 3.28 & 3.41 & 0.94 & 止 & & & \\
\hline 出力 ( KW) & $291^{\prime}$ & 中 & 340 & $303^{\circ}$ & 330 & $158^{9}$ & 中 & $753 .^{\circ}$ & 670.9 & $\triangle 83$ \\
\hline ピーチ又は回転数 & 2 & $\smile$ & 5 & 8 & 7 & $580^{x \cdot \rho m}$ & $\smile$ & & & \\
\hline 形式 & プロペラ & & プロペラ & วัดヘラン & 7ำกラ & 夕ーボ & & & & \\
\hline 立坑圣 (m) & 4.0 & & 5.5 & 4.0 & 4.0 & 4.8 & & & & \\
\hline 俑 & \multirow{2}{*}{\multicolumn{5}{|c|}{ 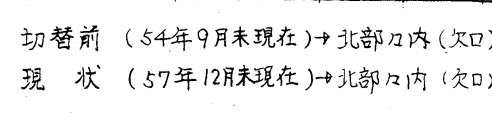 }} & \multirow{2}{*}{\multicolumn{5}{|c|}{ 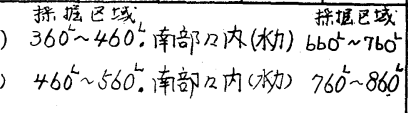 }} \\
\hline 考 & & & & & & & & & & \\
\hline
\end{tabular}

第 7 表 維持坑道長の推移

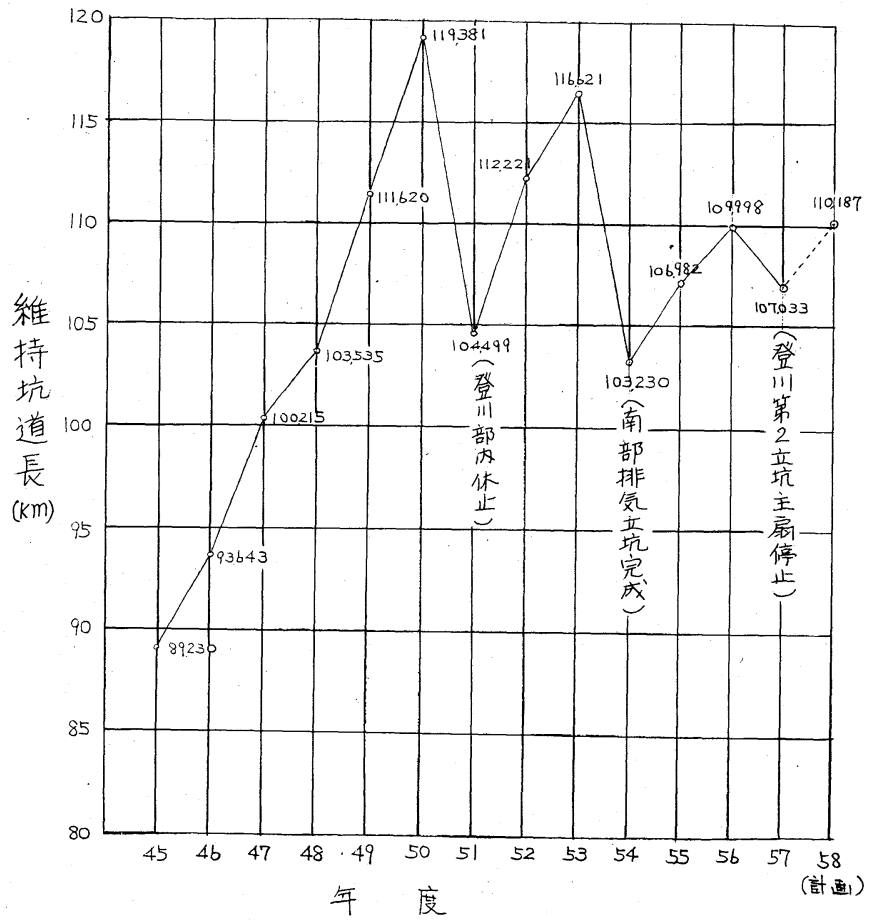

第 8 表 手掘り盤打機の実績対比表

\begin{tabular}{|c|c|c|c|c|c|c|}
\hline 盤打方王 & 箇 & 所 & $\begin{array}{rr}\text { 期 } & \text { (年 } \\
\text { 月 }\end{array}$ & $\begin{array}{l}I \text { 数 } \\
(I / \delta)\end{array}$ & $\begin{array}{l}\text { 工事量深さ } \\
\left(\mathrm{m}^{2} / \mathrm{m}\right)\end{array}$ & 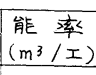 \\
\hline 人百 & bbo南 & & & & & 0.70 \\
\hline 小型艎 & $760^{2} \pm$ & & 56. & 4.0 & 1.34 & 21.70 \\
\hline
\end{tabular}


第 9 表 フライアッシュ流送注入実績対比表

\begin{tabular}{|c|c|c|c|c|c|c|}
\hline & \multicolumn{2}{|c|}{ ポータプルプラント } & \multicolumn{2}{|c|}{$560^{\circ}$ 定置式プラント } & \multirow{2}{*}{ 㒂 考 } \\
\hline & & 平均 & 最高 & 平均 & 最高 & \\
\hline \multirow{3}{*}{$\begin{array}{l}\text { 能 } \\
\text { 力 }\end{array}$} & 注入事数(軎) & 10,4 & 15 & 35 & 62 & 車 $=1.98 \mathrm{~m}^{3}$ \\
\hline & "人点 $\left.(4 /)^{\prime}\right)$ & 3.3 & 4 & 3 & 3 & 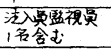 \\
\hline & ＂時间(欲) & 155 & 210 & 143 & 235 & 純注入进時肉 \\
\hline \multirow{2}{*}{ 態 } & 事/分 & 0.067 & 0.071 & 0.245 & 0,264 & \\
\hline & 車/分/人 & 0.020 & 0.018 & 0.082 & 0,088 & \\
\hline
\end{tabular}

打柱を採用した。

(ii) 同䇢所において中打柱の一部に木柱の替わりに摩擦鉄柱を 試用した。

(iii) 岩盤坑道アーチ枠支保型式を従来のA型より, スソ広ガリ のC 型に全面的に切替え, 盤打ちによる坑道断面の有効利用が容 易になつた。

（d）小型盤打機の開発，実用化

小型盤打機を石炭技研と共同開発し，その実用化により，盤打 作業の大幅な改善を行なつた。実績は第 8 表に示すとおりである。

（2）ガス涌出増に対する施策

(a) 昭和56年度にガスブロワー1基 $(130 \mathrm{~kW})$ を增設し 4 基と した。またガス誘導管も中央立坑系を 1 ライン増設し, ガス抜体 制を強化した。誘導ガスは第 1 発電所, ドライヤーおよび新設し た微粉炭, 坑内ガス混焼方式の第 2 発電所 $(7,500 \mathrm{~kW})$ に有効に 利用して，自家発率を $85 \%$ にまで上げた。

(b) ガス抜穿孔能率向上を図るため, P - 4 穿孔機用自在架台 を開発し，現在試用中である。

(3) 自然発火防止に対する施策

(a) 立入着炭部ではボーリング孔を利用して埋設先受けを施工 し, 着炭時の高抜け防止ひいては自然発火の未然防止に効果を上 げている。

(b) フライアッシュ流送プラントの坑内設置 ( $560 \mathrm{~mL}$ 大坑道) により密閉構築能力, 能率の大幅アップと安全性を確立した（第 9 表参照)。

（4）坑内温度に対する施策 南部排気立坑主扇切替による有 効風量の増大および骨格の整備と先行風道の早期掘進体制の確立, その他こまめな対策の積み上げで現在のところ夏場の一時期を除 き問題はなかつた。

(5) その他

(a) モニタ一組枠の実用化 モニタ一噴射時間の延長，およ び資材費節減を図るため，モ二タ一組枠を考案し実用化した。全 切羽に使用するよう推進している (第 3 図参照)。実績は次に示 すとおりである。

資 材 費 節 約 4,000 円 $/$ 方・台 噴射時間増 44 分/方・台

(b) プースタポンプの設置による噴射水圧のアップ 採炭部 内の奥部化によるパイプロス増と一部硬炭区域対策のためブース タポンプ $\left(5.5 \mathrm{~m}^{3} / \mathrm{min} \times 300 \mathrm{~m} \times 2,970 \mathrm{r} \mathrm{pm} \times 450 \mathrm{~kW}\right)$ を設置し, 昇圧化 $\left(100 \mathrm{~kg} / \mathrm{cm}^{2} \rightarrow 137 \mathrm{~kg} / \mathrm{cm}^{2}\right)$ を図ることにより実収率を $8 \%$ 上昇させた。また 1 部内 1 系統 2 モニタ一噴射体制の技術が 確立した。

(c) サンドブラス\&コーティング法によるパイプ内スケール除 去 深部化・奥部化に伴う配管長の増大および経年増による水 力高圧給水管内での圧力損失問題に上記方法で対処した。

パイブは布設状態のままパイプ内クリーニングを行ない, パイ プ内粗度係数 87 を 134 に好転させ圧力損失を $3.13 \mathrm{~m} / 100 \mathrm{~m}$ から $1.25 \mathrm{~m} / 100 \mathrm{~m}$ と著しく減少させ, 切羽末端において約 $8 \mathrm{~kg} / \mathrm{cm}^{2}$ の昇庄効果を上げた。

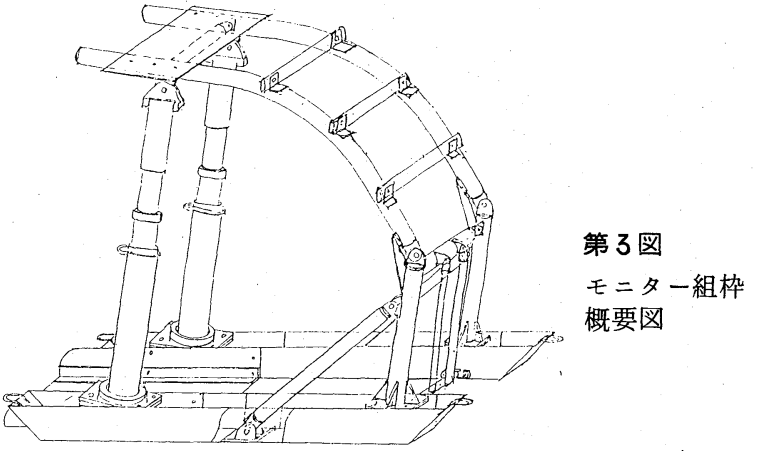

（d） モニタ一用水坑内循環方式の確立 深部移行に伴う給排 水電力費増および保安問題解決のため坑内循環方式を採用した。 これによるメリットとして

(i) 配管長の短縮により $2.239 \mathrm{MWH}$ のポンプ動力の節減とな つた。

(ii) 自然圧は坑外からの給水に比べて $40 \%$ 減 $\left(101 \mathrm{~kg} / \mathrm{cm}^{2} \rightarrow\right.$ $60 \mathrm{~kg} / \mathrm{cm}^{2}$ ) となりウオータハンマ防止上有利となつた。

(e) 微粉炭層に対する施策 深部化に伴い必然的に微粉炭は 増加傾向となり水力採炭給排水中に含まれる微粉が種々トラブル の要因となる。したがつて坑内では下記のような対応策を講じて いる他, 坑外選炭機でも微粉炭処置設備を強化し対処している。

（i）高圧ポンプ摺動部のセラミック化 $210 \mathrm{~kW}$ ( 2 段)ポン プに耐摩耗性に優れたセラミック材を使用し耐用運転時間 $800 \mathrm{~h}$ を $2,960 \mathrm{~h}$ に延長した。

(ii) モニターノズルコーティングの改良（セラミック化）

従来のメタルメッキコーティングノズルの寿命 4,000 分/個 を セラミック化することで 16,000 分/個に延長した。

坑外選炭機での微粉処理対策として

(iii) 浮選機の大型化, 改善の推進を図つた。特に微粉炭脱水機 $(\mathrm{SVS} 900 \times 1,800 \times 20 \mathrm{t} / \mathrm{h})$ の導入により従来のベルトフイルタ 使用より $6 \sim 7 \%$ 精品湿分を低下させた。

(iv) 排水規制 $150 \mathrm{ppm}$ 対策として機械脱水による設備を考え浄 化槽 $\left(360 \mathrm{~m}^{3} / \mathrm{min}\right) 4$ 基, フイルタプレス $(8 \mathrm{t} / \mathrm{h}) 4$ 基。貯水槽 $\left(2,400 \mathrm{~m}^{3}\right) 1$ 基を設置した。

これらによる低品位炭の回収は収支改善に役立つている。

\section{4. 今後の研究課題}

その他深部区域における安定操業を目指し, 現在試験実施中, および試験計画中の課題は下記のとおりである。

$4 \cdot 1$ 試験実施中の課題

(a) 地震計による山鳴計測

(b) 定置式ならびにポータブル式装置による地山 AE の計測

(c) 岩盤変位計測

(d) 大加背坑道でのロックボルト効果の計測

等の現場試験を行ない実績の集績, 分析に取り組んでいる。

\section{$4 \cdot 2$ 試験計画中の課題}

(a) 水力採炭切羽専用小型クラッシャの開発 水力採炭では 各切羽からその部内の脱水機までの間をトラフ内水流しの方法で 石炭を搬送している。今後深部化に伴い大塊や硬などの混入増も 予想されトラフ途中での炭詰り増が懸念される。上記小型クラッ シャを導入し，大塊や硬を簡単に細かく破砕し流すことによりモ ニター噴射時間の延長と省力化を図るものである。

(b) 炭層傾斜等自然条件変化に対応できるフレキシブルなモ二 ターの開発 現状のモニタ一操作機構では炭切りのためのモ二 タ一噴射方向は層理方向と交差せざるを得ない。このモ二ターの 
噴射方向を層理方向とできるだけ一致させるように操作機構を改 善し, 効果的炭切りを図る。また硬炭時にはモニタ一の砲身が伸 びあるいは, 坑道が比較的狭小化している箇所では縮む等のフレ キシブルなモニターを開発し生産性の向上を図る。

(c) 大口径水力穿孔機の開発導入による水力採炭システムの改 善 水力採炭始発部の通気孔さく孔を現状 $\mathrm{P}-4$ 穿孔方式（ 3 $\sim 6$ 本穿孔, $4 \sim 12$ 方, 12 36人所要 ) 加水力穿孔方式 (大口 径 1 本 ) に変更することにより省力化, 工数低減を図る。

またさく孔能率次第ではこれを平常採炭切羽にも導入し，モ二 ターと組合わせることにより硬炭対策にも活用する。

(d) モニター操作方式のフイードバック制御化

(e) 自走モニタ一組枠の開発

(f) 水力採炭モ $=$ タの遠隔操作化

等の課題に対し，その早期実現化を目指し，鋭意取組んでいる。

\section{5. 結言}

深部採掘に伴つて漸増する保安, 生産技術上の諸問題および深 部化・奥部化することによる生産コストの上昇をいかに吸収して いくかはわが国炭鉱技術者共通の悩みと考元る。当砂川炭鉱は現 在地表下約 $900 \sim 1,000 \mathrm{~m}$ 区域において水力採炭技術を有効に駆使 し, 優れた保安成績と高能率の安定した生産体制を維持している。 当所は急傾斜炭鉱として深部移行度が速く，また自然条件として も決して恵まれたものではない。その中でわが砂川技術陣は問 題点と悩みに屈することなく総力を結集して問題解決に当つてき た。

今後の深部化・奥部化に対し，現有技術に満足することなく， 従来にもまして積極的に技術的諸問題の先取り解決を図るべく引 続き努力していく所存である。

\section{Deep Mining at Sunagawa Colliery}

by Masatoshi NISHIDA

Sunagawa Colliery has managed to solve many difficult problems since 1914 and the technical innovation took place in 1964 when the colliery employed hydraulic mining. Subsequently, the hydraulic mining has been steadily improved widening the range of its application. The colliery is now working steeply inclined seams at the depth of 900 to 1000 meters below surface. The author intends to introduce parts of the results successfully practiced in the deep mining at Sunagawa Colliery.

\section{〔2-8〕軽量鉄柱：急傾斜層の安定出炭と機械化の進め方}

\section{1. 緒言}

真谷地炭鉱は, 桂坑, 楓坑, および本沢露天坑の 3 坑口で操業 している。桂坑は夕張層（傾斜 $60 \sim 80^{\circ}$ ) を片盤向偽傾斜欠口式 全充填採炭法で, 日産 $1,100 \sim 1,200 \mathrm{t}$ 程度出炭している。楓坑は 夕張層 (傾斜 $40 \sim 70^{\circ}$ ) を, 原則として傾斜 $45^{\circ}$ 未満を, 平層と 同様に単柱式総ばらしのロング採炭方式を採用し, 傾斜 $45^{\circ}$ 以上 は片盤向偽傾斜欠口式全充媜採炭法早, 日産 $540 \sim 580$ t程度を出 炭, 本沢露天坑では日産 400 430 t 程度出炭し総体で日産 2,000 〜2,100 tの生産規模で操業している。以上いずれも人力による採 炭方式であり, 直接採炭従事者の老令化と若年後継者充足の困難 性という問題点から，急傾斜炭鉱の安定出炭確保をいかにすべき かを近年苦虑していた。昭和54年に国および業界もこの問題を取 り上げ，その対策として鉄柱の軽量化と急立傾斜層の機械化の研 究というテーマで急傾斜技術研究委員会が発足,石炭技術研究所に研 究部門が設けられ，その試験炭鉱の一つとして真谷地炭鈗が選ば れ今日に至つている。その経過と実験の概要について述べること とする。

\section{2. 軽量 鉄柱}

\section{$2 \cdot 1$ 摩擦鉄柱の軽量化}

当炭鉱の稼行対象炭層は夕張層の 1 番上層, 1 番層, 1 番下層, 2 番層, 3 番層の 5 層を対象としており 3 番層は厚層部で $4.40 \sim$ $4.80 \mathrm{~m}$ 所もありこの場合は 2 層に分けて採掘している。したが

1. 北炭真谷地炭鉱株式会社鉱務課長

\section{伊 藤 博 允 $^{1}$}

つて, 平均稼行高さは $2.20 \sim 2.40 \mathrm{~m}$ としている。支保の規格は上， 下盤扮さえは木材 (長さ $2.40 \mathrm{~m}$ 松または雑木で末口 $0.15 \mathrm{~m}$ 以上) とし冠および中張に鉄柱を使用し枠間隔を $1.10 \mathrm{~m}$ とし 6 枠を 2 名 で採掘している。採炭方は穿孔・発破・施枠, 充填方は, 鉄柱を 回収して充填，さらに材料配置の方と 3 方分業方式をとつている。 各番方で取扱う鉄柱の数は採炭方 6 本/人, 充媜方平均 24 本/人, 材料配置の方欠口間の移動補充平均 4 本/人である。この重量は 総重量 $56 \mathrm{~kg}$ /本 で各番方とも傾斜のある足場で操作するため, 軽 量化により疲労度の減少をはかり負傷の減少および, 欠勤 ( 欠勤 による減産）の防止を目的とした検討の結果，鉄柱の下柱をアル ミ系合金とすることにより $5.4 \mathrm{~kg} /$ 本 の軽量化を得て, 総重量 $50.6 \mathrm{~kg} /$ 本となつた。

\section{$2 \cdot 2$ 軽量摩擦鉄柱の使用実績および成果}

当初 ( 56 年度) は軽量摩擦鉄柱切羽と, 従来型鋼製摩擦鉄柱切 羽を区別して, 使用状況の対比を行なつたが, 採炭能率は, ほぼ 同様で切羽総体人員原炭能率 $22 \mathrm{t} /$ 人, 負傷人員の減少では, やは り同様で減少の効果はあらわれていない。出稼率の向上について は, 各切羽の出炭目標があるので, 人員の補充を行なうので, 調 査不能で中止した。成果を把握するため, 試験切羽の作業員, 係 員を対象にして, アンケート調査を行なつた。その結果, 鉄柱の 重量が軽くなつたと全員が感じており, 鉄柱を立柱する時, また 回収する時についても疲労度が小さいと感ずる者が全体の $85 \%$ と 最も多く, 一応の成果は得たと考えている。 57 年度は各切羽で混 用して, 比較研究したが改造により強度があがり破損は年間で 2 本とその破損状況はロールピン穴が切れたもので, この程度の破 損数では一応の成果といつてもよいであろう。その他の項目では 